second year of his work in physics, immediately after the completion of a course in general physics, and to give him a thorough course in the principles of mechanics stated in the language of the calculus and vector analysis, but emphasizing the physics of the subject. The statement of physical facts and concepts in mathematical language is one of the difficult steps in a student's course; and Professor Crew has done well in giving us his introductory course in the mathematical side of physics.

The book is written in a style which is always clear and interesting. The forms of statement are fresh, and the author has drawn on a wide range of reading and experience for new and apt illustrations.

\section{A. P. Carman}

\section{The Evolution of Forces. By Gustave LeBon.} Pp. 388. New York, D. Appleton \& Co. 1908.

In the controversy between Mr. Norman Campbell, of Trinity College, Cambridge, and Mr. F. Legge, of the Royal Institution, concerning Dr. LeBon's writings, Mr. Campbell said:

I was a student of that author's works two years before his book appeared, and I believe that I have read every word that he has ever published on physical questions. ${ }^{1}$

On the basis of this thorough knowledge, Dr. Campbell places an extremely low estimate upon LeBon's work.

I have not read all of LeBon's writings by any means, but very certainly the present book on "The Evolution of Forces" is of little or no account, except in one respect only. If one wished to diagnose the ills of contemporary French science, one would find in LeBon exaggerated symptoms of a malady (not of course affecting all French scientists) which has resulted from the tremendous scientific preeminence of the French during the early part of the nineteenth century. Let one consider the state of mind of a man who can express himself after the manner of the following quotations which are taken almost at random from LeBon's book:

${ }^{1}$ The Athenaum, March 3, 1906.
This happy confidence in the great dogmas of modern science remained unaltered until the quite recent date when unforeseen discoveries condemn scientific thought to suffer doubts from which it imagined itself forever free.

There should, therefore, be no hesitation to examine closely the fundamental dogmas of science, for the sole reason that they are venerated and at first sight appear indestructible.

After I had proved that the dissociation of atoms was a universal phenomenon and that matter is an immense reservoir of energy hitherto unsuspected in spite of its colossal grandeur, etc.

Speaking of a certain matter, LeBon says:

As I expected, it was one of those classic errors repeated without verification to which repetition at length gives indisputable authority.

Speaking of another matter, he says:

All authors have regarded it as having a preponderating influence.

There is one idea which, according to $\mathrm{my}$ experience, seems to be dominant in the minds of young students, namely, that the physical science which they study in the technical school or college is in the text-book and was created by a literary effort of an author. Dr. LeBon, apparently, has never got beyond this childish idea. The word author, as applied to a scientist, is misleading. Our scientific men in the United States do not combine sufficiently the ability to write with the ability to search and search again, so that, although it is mildly ridiculous to call many of them authors, it would be a distinct affront to speak of them narrowly as such.

W. S. Frankuin

\section{Contribution toward a Monograph of the} Laboulbeniaceae. By Roland Thaxter. Part II. With 54 plates. Memoirs of the American Academy of Arts and Sciences, Vol. XII., No. VI. 4to, pp. 219-461. Cambridge, printed by Edward W. Wheeler. June, 1908.

Nineteen years ago Dr. Thaxter published his first paper on the Laboulbeniaceae, ${ }^{1}$ and since that time has brought out many papers in which he has steadily added much to our knowledge of the species and genera and still

1 " On Some Species of North American Laboulbeniaceae," Proc. Am. Acad. Arts and Sci., Vol. XXIV., February, 1890. 
more of the structure and development of these curious entomogenous fungi. About twelve years ago he brought out " a stately quarto volume of two hundred and forty-two beautifully printed pages and twenty-six plates crowded with six hundred and seventytwo elegantly drawn figures," which the present writer reviewed in the American Naturalist (1897, p. 513). In this volume, which bore the same title as the one now before us, 28 genera and 158 species were recognized. And now in the second volume these numbers are increased to "more than fifty genera," and "about five hundred species and varieties." And we are told that since the completion of the plates "considerably more than one hundred additional new species have already accumulated," of which it is the author's expectation to publish figures and descriptions "with as little delay as possible."

The present publication adds to our knowledge of the structure of these plants in an instructive introductory chapter. In a brief and cautious discussion of their relationship Dr. Thaxter says:

They are more surely Ascomycetes than many forms included in this group, and the writer sees no sufficient reason why they should not be placed in the Pyrenomycetes, as a group coordinate with Perisporiales, Hypocreales, etc.

In the systematic portion of the work the genera are arranged under two groups (orders?) viz., (I.) Laboulbeniineae, in which the antheridia are composed of "specially differentiated cells or groups of cells," and (II.) the Ceratomycetineae, in which the antheridia are composed of "more or less undifferentiated cells of the appendages or of their branches." In the first three are two families (?) viz., (1) Peyritschiellaceae (of 19 genera), with compound antheridia, and (2) Laboulbeniaceae (of 28. genera), with simple antheridia. The second order (?), which is composed of mostly aquatic plants, contains eight genera. The 44 plates are, if anything, better even than those in the previous volume, and enable one to get some idea of the structure of these very curious plants.

Dr. Thaxter asks his correspondents to communicate any additional material they may have, and it may be well to repeat here the suggestions he made in his earlier contribution in regard to the collection and preparation of Laboulbeniaceae for study (pp. 248-249).

The collection of Laboulbeniaceae involves little more than the collection of a sufficient number of the proper hosts, although their presence on the latter is not always easy to ascertain in case of the smaller forms. In so far as concerns the collection of hosts my own experience ... indicates that the most favorable localities in which to search for infested beetles is along the margins of small streams or of ponds. ... Traps deposited in such situations, and made by raking together a heap of decaying grass, algae, etc., often yield large numbers of interesting specimens. Many forms may also be obtained by leaving bundles of hay or grass in cultivated ground for a few days and examining them over a sheet. Water beetles are in general best obtained by sweeping the margins of ponds or ditches witn a dip-net. . . . Having obtained a number of hosts which are liable to be parasitized, it will be found that from about five to fifty per cent. will bear parasites. In order to obtain them for examination the host should be killed and impaled on a fine needle, care being taken that the surface of the insect remains perfectly clean and dry, and then examined over a dull white, and then over a black surface, with a hand lens magnifying about eight or ten diameters. . . Every portion of the insect should be examined in different positions. ...

Here is an opportunity for botanical collectors to exploit a new field near home, with the probability that new species or new hosts may be discovered. Any beetles on which these minute plants are found should be carefully packed, wet or dry, in clean cotton and sent to Dr. Thaxter, Cryptogamic Laboratory, Harvard University, Cambridge, Mass.

\section{The University of Nebraska}

Charles E. Bessey

The Loose Leaf System of Laboratory Notes. By Theo. H. Scherfer, A.M. Philadelphia, P. Blakiston's Son \& Company. 1908.

It fell to the lot of the present writer to review in ScIEnce of December 28, 1906, the first edition of this manual. The publishers have recently issued a "second edition, re- 